\title{
The «Dublin IV» Proposal: Towards more solidarity and protection of individual rights?
}

Sarah Progin-Theuerkauf*

The Achilles' heel of the Dublin system is and has always been the lack of solidarity between the Member States and the relatively poor standard of protection of individual rights of the concerned applicants for international protection. In May 2016, the EU Commission has published a proposal to reform the Dublin III Regulation. Will the recast regulation achieve the aim of creating «a more sustainable and fair Common European Asylum System», as announced by the Commission? The following article discusses and analyses the Dublin IV proposal in the light of the principle of solidarity and the EU's obligation to protect fundamental rights of migrants.

I. Background .62

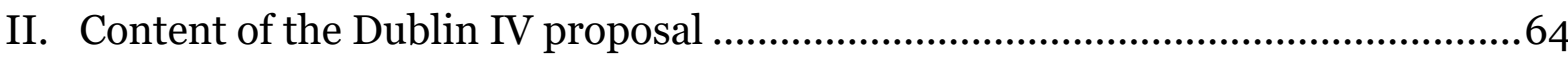

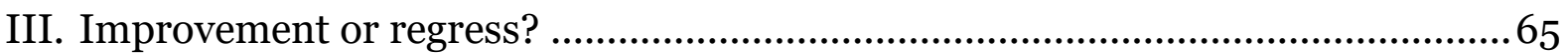

1. Will the suggested changes enhance solidarity between the EU Member States? . .65

2. Will the Dublin IV proposal improve the situation of Asylum seekers in the EU? .66

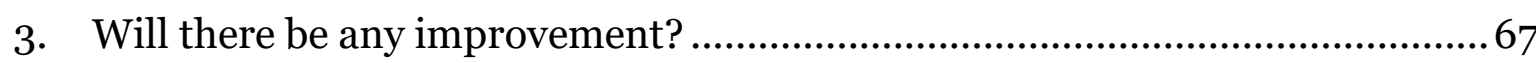

IV. Conclusion .67

Zitiervorschlag: Sarah Progin-Theuerkauf, The «Dublin IV» Proposal: Towards more solidarity and protection of individual rights?, in: sui-generis 2017, S. 61

URL: $\quad$ sui-generis.ch/34

DOI: $\quad$ https://doi.org/10.21257/sg.34

Sarah Progin-Theuerkauf is Associate Professor for EU Law and Migration Law at the University of Fribourg and Co-Director of the Centre for Migration Law of the Universities of Berne, Neuchâtel and Fribourg.

Dieses Werk ist lizenziert unter einer Creative Commons Namensnennung - Weitergabe unter gleichen Bedingungen 4.o International Lizenz. 


\section{Background}

1 On May 4, 2016, the European Commission has published three proposals to reform the Common European Asylum System ${ }^{1}$. They are the first series of two legislatives packages the Commission has presented in 2016 to tackle the current «refugee crisis» ${ }^{2}$. One of the proposals

1 Proposal for a Regulation of the European Parliament and of the Council $\operatorname{COM}(2016) 270$ final): establishing the criteria and mechanisms for determining the Member State responsible for examining an application for international protection lodged in one of the Member States by a third-country national or a stateless person (recast); Proposal for a Regulation of the European Parliament and of the Council (No 439/2010, $\operatorname{COM}(2016) 271$ final): on the European Union Agency for Asylum and repealing Regulation (EU); Proposal for a Regulation of the European Parliament and of the Council (No 604/2013, $\operatorname{COM}(2016) 272$ final): on the establishment of 'Eurodac' for the comparison of fingerprints for the effective application of establishing the criteria and mechanisms for determining the Member State responsible for examining an application for international protection lodged in one of the Member States by a third-country national or a stateless person, for identifying an illegally staying third-country national or stateless person and on requests for the comparison with Eurodac data by Member States' law enforcement authorities and Europol for law enforcement purposes (recast).

2 A second package was proposed on July 13, 2016: Proposal for a Regulation of the European Parliament and the Council (2013/32/EU, COM (2016) 467 final): establishing a common procedure in the Union and repealing Directive; Proposal for a Regulation of the European Parliament and Council (COM(2016) 466 final): on standards for the qualification of third-country nationals or stateless persons as beneficiaries of international protection, for a uniform status for refugees or for persons eligible for subsidiary protection and for the content of the protection granted and amending Council Directive 2003/ 109/EC of 25 November 2003 concerning the status of third-country nationals who are long-term residents; Proposal for a Directive of the European Parliament and of the Council (COM(2016) 465 final): laying down standards for the reception of applicants for international protection (recast); Proposal of the European Parliament and the Council (No 516/2014, COM(2016) 468 final): for a Regulation establishing a Union Resettle- (the «Dublin IV» proposal) intends to amend the Dublin system 3 , the controversial cornerstone of the Common European Asylum System.

2 The Dublin system was established in 1990, when the twelve members of the European Economic Community signed the Dublin Convention4, an International Agreement5. It entered force in 1997. With the Amsterdam Treaty, the European Community gained more competences for the area of Asylum Law ${ }^{6}$. The Dublin Convention was then «communitarised» and turned into the Dublin II Regulation7. In 2013, the Dublin II regulation became the Dublin III Regulation ${ }^{8}$, with little changes. The idea of the Dublin system is to establish criteria that help to

ment Framework and amen-ding Regulation (EU).

3 Regulation of the European Parliament and of the Council (No 604/2013): establishing the criteria and mechanisms for determining the Member State responsible for examining an application for international protection lodged in one of the Member States by a third-country national or a stateless person, OJ L 180, 29.6.2013, p. 31-59.

4 Convention determining the State responsible for examining applications for asylum lodged in one of the Member States of the European Communities - Dublin Convention, OJ C 254, 19.8.1997, p. $1-12$.

5 For a historic overview, see Sarah Progin-Theuerkauf, Art. 78 AEUV, in: Von der Groeben /Schwarze/Hatje (Hrsg,), Europäisches Unionsrecht, p. 7. Auf-lage 2015, notes 1 et seq.

6 Article 63 EC-Treaty.

7 Council Regulation (EC) (No 343/2003 of 18 February 2003): establishing the criteria and mechanisms for determining the Member State responsible for examining an asylum application lodged in one of the Member States by a third-country national, OJ L 5O, 25.2.2003, p. 1-10.

8 Regulation (EU) of the European Parliament and of the Council (No 604/2013 of 26 June 2013): establishing the criteria and mechanisms for determining the Member State responsible for examining an application for international protection lodged in one of the Member States by a third-country national or a stateless person, OJ L 180, 29.6.2013, p. 31-59. 
identify the Member State responsible for the examination of an application for international protection. There is only one responsible Member State for each claim («one chance only»). «Asylum shopping» is not permitted9.

3 Two aspects have always been criticized about the Dublin system: Firstly, it is said to impose a more substantial burden on Member States at the external border of the European Union ${ }^{10}$ due to its Article 13(1), which says that a Member State where an applicant has irregularly crossed the border coming from a third country is responsible for the assessment of his or her asylum claim. Secondly, the system does not properly take into account fundamental rights of the persons concerned ${ }^{11}$.

4 According to the European Commission, the 2016 proposal aims at «creating a fairer, more efficient and more sustainable system for allocating asylum applications among Member States»12. Although the Dublin system was originally not in-

9 Sarah Progin-Theuerkauf, Das Dublin-System, On the move, 29.3.2016.

10 However, it is contested whether this is really the case, as other states (without external borders) have been the major recipients of asylum seekers in the last years. It is also difficult to evaluate how heavy the burden really is, as this does not depend on absolute numbers of asylum claims, but also on the relative capacity of a country to receive (and integrate) asylum seekers. Cf. Madeline Garlick, Solidarity under strain, 2016, p. 163.

11 Judgment of the Court (Grand Chamber) C411/10 and 493/10 of 21 December 2011; Judgment of the Court (Fourth Chamber) C-648/11 of 6 June 2013 (MA, BT, DA versus Secretary of State for the Home Department); Judgment of the Court (Fourth Chamber) C-63/15 of 7 June 2016 (Mehrdad Ghezelbash versus Staatssecretaris van Veiligheid en Justitie): Judgment of the Court (Grand Chamber) C-155/15 of 7 June 2016 (George Karim versus Migrationsverket).

12 European Commission (IP/16/1620), Press release of 4 May 2016. tended as a burden sharing instrument ${ }^{13}$, the obligation to create a system that is more solidary than the current one can be derived from Article 80 TFEU14, inserted into the TFEU by the Lisbon Treaty (2009). It is also evident that the protection of fundamental rights ${ }^{15}$ of concerned persons has to be guaranteed. The Stockholm Programme ${ }^{16}$ of December 2009 already called for a Common European Asylum System «based on high protection standards»17. It added that «effective solidarity with the Member States facing particular pressures should be promoted ${ }^{18}$.

5 In its communication of April 6, 2016 19 , the European Commission also called for reforms and confirmed the conclusion that the Dublin system is not functioning properly: «The overall objective is to move from a system which by design or poor implementation places a disproportionate responsibility on certain Member States and encourages uncontrolled and irregular migratory flows to a fairer system which provides orderly and safe

13 Cf. Madeline Garlick, Solidarity under strain, 2016, p. 162.

14 Article 80 TFEU: «The policies of the Union set out in this Chapter and their implementation shall be governed by the principle of solidarity and fair sharing of responsibility, including its financial implications, between the Member States. Whenever necessary, the acts of the Union adopted pursuant to this Chapter shall contain appropriate measures to give effect to this principle.»

15 Mainly Articles 4, 7, 18, 19, 24, 33, 35, 41 and 47 of the Charter on Fundamental Rights of the European Union.

16 Council of the European Union (17024/09): The Stockholm Programme - An open and secure Europe serving and protecting the citizens.

17 Point 6.2 of the Stockholm Programme.

18 Point 6.2.2. of the Stockholm Programme.

19 Communication from the Commission to the Euro-pean Parliament and the Council (COM (2016) 197 final): Towards a reform of the Common European Asylum System and enhancing legal avenues to Europe. 
pathways to the EU for third country nationals in need of protection or who can contribute to the EU's economic development. The EU needs a robust and effective system for sustainable migration management for the future that is fair for host societies and EU citizens as well as for third country nationals and countries of origin and transit. For it to work, this system must be comprehensive, and grounded on the principles of responsibility and solidarity.»

6 In May 2016, the European Commission seemed somewhat less determined to modify the Dublin system: In its press release $^{20}$ announcing the first three proposals to reform the Common European Asylum System, it stated that regarding the allocation of asylum seekers among the Member states, "the basic principle will remain the same.» However, the Commission continues to declare that «today's proposal will make the Dublin System more transparent and enhance its effectiveness, while providing a mechanism to deal with situations of disproportionate pressure on Member States' asylum systems. The new system is designed to be fairer but also more robust, one that is better able to withstand pressure.»

7 But which changes will the Dublin IV proposal really entail? Will it really bring forward solidarity between the Member States? Will it lead to a better treatment of asylum seekers in Europe? These two questions will be examined in the present article.

20 European Commission (IP/16/1620), Towards a sustainable and fair Common European Asylum System, press release of 4 May 2016

\section{Content of the Dublin IV proposal}

8 The main changes to the Dublin III Regulation that the Commission suggested in its Dublin IV proposal are the following:

- A corrective allocation mechanism (fairness mechanism) will be created, which will automatically be established when a country has to handle a disproportionate number of asylum applications - considering the country's size and wealth. If one country receives applications exceeding $150 \%$ of the reference number, all further new applicants (regardless of their nationality) will be relocated across the EU. This applies until the number of applications is back below that level. A Member State has the option of temporarily not taking part in the reallocation. In that case, it has to pay a «solidarity contribution» of $€$ 250'000 for each person refused to the Member State the person is allocated to instead;

- A special pre-procedure will be introduced (that actually petrifies the «Turkey deal»): It starts with an obligation to introduce a claim for international protection in the Member State of first irregular entry. The Member State then has the obligation (not: the possibility) to check whether the application is inadmissible, on the grounds that the applicant comes from a first country of asylum or a safe third country. If this is the case, the applicant will be returned to that country. If the person comes from 
a safe country of origin or presents a security risk, the application must be dealt with in an accelerated procedure;

- Legal obligations for applicants for international protection will be introduced, the above-mentioned obligation to deposit their asylum claim in the first country they enter will be fortified by a duty to remain in the Member State responsible for their claim, geographically limited reception benefits, and sanctions in case of noncompliance;

- Shorter, but not binding time limits for sending transfer requests, receiving replies and carrying out transfers of asylum seekers between Member States will be included in the Regulation;

- Shifts of responsibility will be removed (for example the expiry of deadlines for replying to take charge requests);

- Deadlines for the exercise of a person's right to an effective remedy against a transfer decision will be shortened (7 days);

- The responsibility criteria will be streamlined (for example, the abolition of the cessation of responsibility after 12 months from irregular entry);

- A new responsibility criterion for unaccompanied minors will be introduced: In the absence of family members or relatives, the country where the first asylum application was lodged shall be responsible for the examination of an asylum application of an unaccompanied minor;

- The Dublin system will be applied to recognized beneficiaries of international protection.

\section{Improvement or regress?}

9 In the following, the suggested modifications will have to be checked for their real value in the light of the claim for more solidarity, while at the same time safeguarding individual rights of asylum seekers.

\section{Will the suggested changes enhan-} ce solidarity between the EU Member States?

10 As highlighted above, one of the major shortcomings of the Dublin system is the lack of sharing of responsibility between the Member States. However, the proposal still places the main burden on the Member States with external borders (Italy, Greece). The objective of ensuring an equitable distribution of applicants for international protection among and thus a certain degree of solidarity between the Member States will not be reached.

11 The new «fairness mechanism» will most likely never be applied, as the reference numbers will never be exceeded: With most of the applicants coming from a «safe» third country (Turkey...), a very high number of them will have to be sent back there after the pre-procedure. 
12 The obligation to introduce a claim for international protection in the Member State of first irregular entry will further contribute to the burden of the Member States at the external borders of the EU. The same is valid for the abolished possibility of cessation of responsibility in case of irregular crossing of an external border: The Member States at the borders will remain responsible forever.

As to the idea of paying a solidarity contribution of $€ 250$ '0oo to another Member State who is willing to take over the asylum seeker is simply absurd. Firstly, because the amount is totally arbitrary: For persons easy to integrate, it is far too high, but for persons that will need to receive social assistance over many years, it seems rather low. Secondly, because it is actually not a sign of solidarity, but the exact opposite: It will allow Member States not willing to be solidary to buy themselves out of the system. Moreover, it will be impossible to execute this provision in practice, as Member States would have to transfer money back and forth all year long.

14 Therefore, the proposal clearly falls short of enhancing more solidarity between the Member States.

\section{Will the Dublin IV proposal im-} prove the situation of Asylum seekers in the EU?

Actually, due to the new pre-procedure, it will be more and more difficult to have one's asylum claim assessed in the EU. The pre-procedure might also bear the risk of a violation of the principle of family unity, as persons will be sent back notwithstanding the presence of family members in the EU. In fact, the Dublin
IV proposal cements the EU-Turkey deal. If Turkey is considered a safe third country (meaning that it is safe for third country nationals; not necessarily for Turks, which is contested), the majority of asylum seekers that enter the EU will be sent back to Turkey, not because of the deal (whose qualification as a legally binding agreement is uncertain ${ }^{21}$ ), but because of the explicit provisions of the new Dublin regulation.

16 The new legal obligations for applicants for international protection to deposit their claims and to remain in the first country of irregular entry (along with the sanctions in case of non-compliance) also bear the risk of human rights violations. Namely, families might remain separated for an excessively long period.

17 Moreover, shorter time limits throughout the whole procedure will not only cause infringements of individual rights, but also might increase the already high pressure on Member States' authorities (even if they are not binding), almost certainly leading to more cursory assessments of the individual cases.

18 All in all, the protection of fundamental rights of asylum seekers is clearly weakened by the proposal.

21 Order of the general Court (First Chamber, Extended CompositionT-192/16 of 28 February 2017 (NF versus European); Order of the general Court (First Chamber, Extended Composition) T193/16 of 28 February 2017 (NG versus European Council); Order of the general Court (First Chamber, Extended Composition) T-257/16 of 28 February 2017 (NM versus European Council). 


\section{Will there be any improvement?}

19 It is difficult to identify at least some positive points of the proposal: Only the harmonization of the notion of family members and the introduction of a maximum period for detention (6 weeks) can be judged as some kind of material progress. What regards all the rest, the proposal will rather lead to a worsening of the situation of applicants for international protection in the EU, than to a better functioning of the system.

\section{Conclusion}

20 Considering the history of the Common European Asylum System and landmark cases $^{22}$ of the European Court of Justice in the area of asylum, the proposal seems premature and incoherent. Some of the suggested modifications undeniably increase the risk of human rights violations of applicants for international protection. The proposal therefore appears to be just another hasty reaction to the so-called «refugee crisis», allowing the EU to prove critical Member States that efforts are being made. The proposal also reflects the prevailing tendencies in the EU regarding the regulation of migration: Regaining control of the situation, ending large-scale «irregular movements» and «protecting» the EU's external borders are the primary goals. That's why some legal scholars also denunciated an «Orbanisation» 23 of EU Asylum Law.

22 For instance Judgment of the Court (Fourth Chamber) C-648/11 of 6 June 2013 (MA, BT, DA versus Secretary of State for the Home Department); Judgment of the Court (Grand Chamber) C-411/10 and 493/10 of 21 December 2011.

23 Steve Peers, The Orbanisation of EU asylum law: the latest EU asylum proposals, EU Law Analysis, 6 May 2016.
21 As a conclusion, one can say that, compared to the currently applicable system, there is no real added value of the Dublin IV proposal. On the contrary: It would rather add to the existing problems, as it will not be able to encourage Member States to commit to more solidary among each other and to a better treatment of asylum seekers. It is hard to imagine that such an instrument will find consensus in the Council and the Parliament. But: Some elements of the proposal might survive the ongoing negotiations. And these could still cause enough harm to the already weak position of migrants in Europe $^{24}$.
24 See also Sarah Progin-Theuerkauf, The «Dublin IV» proposal, One step forward and ten steps back, On the move, 1.9.2016. 